\title{
The effect of the replacement of fat with carbohydrate-based fat replacers on the dough properties and quality of the baked pogaca: a traditional high-fat bakery product
}

\author{
Seher SERIN ${ }^{1}$, Sedat SAYAR ${ }^{1 \star}$
}

\begin{abstract}
Pogaca is a traditional high-fat bakery product in Turkey. This study was conducted to evaluate the effect of fat replacement in pogaca formulation by various amounts $(5,10$ and $15 \mathrm{~g}$ on $100 \mathrm{~g}$ wheat flour basis) of inulin, polydextrose and maltodextrin on the properties of dough and quality of pogaca. Dough stickiness values were increased by increasing the amount of fat replacer at the all fat reduction levels (20,30 and 40\%) studied. Extensibility and resistance to extension values of dough were also significantly changed due to the fat replacement. Sensory analysis of pogaca showed that the formulations prepared by maltodextrin and polydextrose generally received higher scores than the formulation prepared by inulin. Overall, it was observed that up to $30 \%$ of the fat can be replaced in pogaca formulation without any decrease in the physical, textural and sensory quality of pogaca.
\end{abstract}

Keywords: dough stickiness; fat replacer; pogaca; sensory analysis.

Practical Application: Reducing the fat level of the bakery products has a positive impact on human health.

\section{Introduction}

Pogaca is a traditional bakery product consumed by most of the population in Turkey. The studies that examined the dietary habits of various groups of people in Turkey determined that almost $35 \%$ of the general population prefer to consume pogaca in the breakfast (Sevindi et al., 2007; Unsal, 2008; Güleç et al., 2008). Pogaca are generally prepared fresh for breakfast. The most important quality parameters of pogaca are its texture and flavour. Pogaca traditionally contains about up to $28-30 \%$ of fat, which influences the rheological properties of pogaca dough and physical properties of the baked product. It is known that fat interacts with other ingredients to develop and mould texture, mouthfeel and overall smoothness of the baked products (Sudha et al., 2007; Giese, 1996; Stauffer, 1998). On the other hand, such a high content of fat, significantly decrease the consumer preferences for pogaca, since the consumption of high quantities of fat becomes one of the major nutritional problems today. It has been reported that high fat intake is directly associated with various health disorders such as obesity, cancer, high blood cholesterol and coronary heart disease (Akoh, 1998). Therefore, great effort has been made to reduce the fat from food formulations without affecting their flavor and texture (Nonaka, 1997).

Fat replacers are substances that can be used in different foods to mimic the textural and sensory attributes provided by fat, but give considerably lower amount of calories. Replacement of fat by different type of fat replacers in various foods has been studied in the literature. The fat replacers can be carbohydrate based, protein based or lipid based. Carbohydrate-based fat replacers, like dextrins, modified starches, and hydrocolloids, have been reported to mimic fat by binding water and providing smoothness and a desired mouthfeel (Bath et al., 1992; Nonaka,
1997; Akoh, 1998). It has been found that gel-like matrices are formed by carbohydrate-based fat replacers form at the presence of substantial levels of water, resulting in lubricant and flowing properties similar to those of fats in some food systems (Hassel, 1993; Yackel \& Cox, 1992). There have been several commercial carbohydrate-based fat replacers available so far. Maltodextrin, is a non-sweet starch hydrolysate and used as swelling agent (Alexander \& Zobel, 1992). Polydextrose is a complex carbohydrate made from glucose, sorbitol and citric acid with a relatively high viscosity in solution and good mouth feel and creaminess, which has been involved in some fat reduced formulations including biscuits (Mitchell, 1996). Inulin is another carbohydrate-based fat replacer which is indigestible polysaccharide, also known as fructans. It has good fat imitating properties, when combined with water due to the ability to form a gel. (O'Brien et al., 2003). Food scientists are still expanding great effort to find the best fat replacer for particular food that can replace fat with minimum change in the physicochemical and sensory properties of food.

Therefore, the aim of the present study is to assess the effects of polydextrose, maltodextrin and inulin used as a fat replacer with three different amounts in reduced fat pogaca samples on the properties of the dough and on the physical and sensory properties of the pogaca.

\section{Materials and methods}

\subsection{Materials}

Wheat flour of $12.48 \%$ moisture (AACC Method 44-19; American Association of Cereal Chemists, 1995), 0.54\% ash (ICC 104/1), 449 s Falling number (AACC Method 56-81; 
American Association of Cereal Chemists, 1995), and 62\% gluten index (AACC Method 8-12A; American Association of Cereal Chemists, 1995) was used. Fat, yogurt, egg, sugar, salt and yeast were purchased from the local markets. The fat replacers, inulin, maltodextrin $(\mathrm{DE}=18-20)$ and polydextrose were the product of Beneo-Orafti (Tienen, Belgium), CJ Cheiljedang (Seoul, South Korea), and Zhucheng Dongxiao Biotechnology (Shandong, China), respectively.

\subsection{Pogaca preparation}

The ingredients used in each pogaca formulation are given in Table 1. Typical (traditional) pogaca formulation was used as the control formula. The rate of fat reduction levels selected were $20 \%, \% 30$ and $40 \%$. Fat replacers were used in three different amounts $(5,10,15 \mathrm{~g} / 100 \mathrm{~g}$ flour $)$ in the all pogaca formulations.

Pogaca samples were prepared according to the following procedure. Fat was mixed with sugar, salt, yeast, yogurt and egg white in a mixer for $3 \mathrm{~min}$ at low speed. Then fat replacer solution and flour were added and mixed for another $3 \mathrm{~min}$ at high speed using a KitchenAid mixer (Model APM10, St. Joseph, MI, USA). The dough was divided into pieces of $90 \mathrm{~g}$ one. The pieces were rounded and molded to obtain a desirable shape and then was covered with egg yolk. Dough fermentation was performed at $45^{\circ} \mathrm{C}$ for $30 \mathrm{~min}$. Pogaca was baked at $180^{\circ} \mathrm{C}$ for $20 \mathrm{~min}$. After baking, the pogaca was removed from the oven and allowed to cool to room temperature for 1 hour.

\subsection{Dough analysis}

\section{Stickiness test}

Dough stickiness tests were carried out with a TA.XT2 texture analyzer (Stable Micro Systems Ltd., Surrey, UK) using the SMS/Chen-Hoseney dough stickiness rig (A/DSC) and a $25 \mathrm{~mm}$ perspex cylinder probe (P/25P) (Hoseney \& Smewing, 1999). Test parameters: Pre-Test Speed: $0.5 \mathrm{~mm} / \mathrm{s}$, Test speed: $0.5 \mathrm{~mm} / \mathrm{s}$, Post-Test Speed: $10.0 \mathrm{~mm} / \mathrm{s}$, Distance: $4 \mathrm{~mm}$, Force: 40 g, Time: 0.1 s, Trigger-Type: Auto-5 g, Data Acquisition Rate: 100 pps. The force-time curves were analysed with the test program 'Measure of Dough Stickiness' (Texture Expert Exeed, Stable Micro Systems, Surrey, UK). The dough stickiness

Table 1. Formulation for pogaca preparation.

\begin{tabular}{lcccc}
\hline \multirow{2}{*}{ Ingredients } & \multicolumn{4}{c}{ Rate of fat reduction, \% } \\
\cline { 2 - 5 } & 0 (Control) & 20 & 30 & 40 \\
\hline Flour (g) & 100 & 100 & 100 & 100 \\
Shortening (g) & 50 & 40 & 35 & 30 \\
Sugar (g) & 6 & 6 & 6 & 6 \\
Salt (g) & 2 & 2 & 2 & 2 \\
Yeast (g) & 10 & 10 & 10 & 10 \\
Egg white (g) & 13.2 & 13.2 & 13.2 & 13.2 \\
Water (ml) & 2 & $6^{2}$ & $6^{2}$ & $6^{2}$ \\
Yogurt (g) & 17.5 & 17.5 & 17.5 & 17.5 \\
Fat replacer $(\mathrm{g})^{1}$ & 0 & 5,10 or 15 & 5,10 or 15 & 5,10 or 15 \\
\hline
\end{tabular}

${ }^{1}$ Three different amount of fat replacer were examined for each fat reduced pogaca formulation. ${ }^{2}$ Amount of water increased for obtaining a processable dough. is described as positive maximum force. All measurements were conducted five times for each replicates. The average was calculated in force unit (g).

\section{Extensibility test}

Dough extensibility and extensibility force tests were carried out with a TA.XT2 texture analyzer (Stable Micro Systems, Ltd, UK) using Kieffer dough and gluten extensibility rig equipped with a $5 \mathrm{~kg}$ load cell (Kieffer et al., 1998). The dough sample that rested for $30 \mathrm{~min}$ at $45^{\circ} \mathrm{C}$ was placed on the teflon saw plate to make dough strips for further extensibility analyses. Test parameters: Pre-Test Speed: $2.0 \mathrm{~mm} / \mathrm{s}$, Test speed: $3.3 \mathrm{~mm} / \mathrm{s}$, Post-Test Speed: $10 \mathrm{~mm} / \mathrm{s}$, Distance: $75 \mathrm{~mm}$, Trigger force: Auto-5 g, Data acquisition rate: 200 pps. The extensibility was determined as the distance at sample rupture and resistance to extension was the maximum peak force. These tests were performed at least for five dough strips for each dough sample and the corresponding averages were calculated.

\subsection{Pogaca analysis}

\section{Sensory evaluation}

Freshly baked pogaca samples were stayed at room temperature for $1 \mathrm{~h}$ before sensory analysis. Sensory evaluation of the pogaca samples were carried out by 14 panellists (aged between 19 to $53 \mathrm{y}$ ). Panel members were informed about the quality parameters of pogaca during the training sessions, according to the procedures given by Meilgaard et al. (2007). Sensory tests were carried out in particular room, which was away from the sample preparation units. The temperature of the room was maintained at $25^{\circ} \mathrm{C}$. The panel members, abstained from eating, drinking or smoking for at least $1 \mathrm{~h}$ prior to testing. Samples were presented to the panellist on white plastic plates which randomly coded. Pogaca samples were evaluated on a five-point hedonic scale for appearance, internal cross-sectional view, softness, stickiness, flavour and overall acceptability. Panellists evaluated the sensory properties of pogaca based on their degree of like, where 1, 2, 3, 4 and 5 correspond to "dislike very much", "dislike moderately", "neither like nor dislike", "like moderately" and "like very much", respectively.

\section{Firmness test}

Pogaca firmness was determined according to the Standard Method 74-09 (American Association of Cereal Chemists, 2000) using the Texture Analyzer TA-XT2 (Stable Micro Systems, Ltd., UK). After cooling for 1 hour in room temperature, pogaca slices of $1.25 \mathrm{~cm}$ were prepared. The force were measured at which the height of the pogaca slices and the whole pogaca crust were compressed by $25 \%$ using $25 \mathrm{~mm}$ diameter cylindrical probe with pre-test speed of $1 \mathrm{~mm} / \mathrm{s}$, test speed of $1.7 \mathrm{~mm} / \mathrm{s}$, post test speed of $10 \mathrm{~mm} / \mathrm{s}$, distance of $10 \mathrm{~mm}$ and trigger force of Auto-5 g. All measurements were conducted for five times for each replicates. The maximum peak force value was recorded for each measurement, and the average was calculated in force unit (g). 


\section{Colour analyses}

A machine vision system (Luzuriaga et al., 1997) was used to investigate colour changes of the pogaca crust surface and pogaca slices in which fat was replaced with polydextrose, maltodextrin and inulin. The values of $L^{*}$ (lightness/darkness), $\mathrm{a}^{*}$ (redness /greenness), and $\mathrm{b}^{\star}$ (yellowness/blueness) were recorded.

\section{Volume analyses}

Sample volume were measured by the colza seed displacement method (American Association of Cereal Chemists, 1995), after the pogaca was cooled for 1 hour.

\section{Moisture analyses}

Moisture content of pogaca samples were determined according to the Standard Method 44-15A (American Association of Cereal Chemists, 1995).

\subsection{Statistical analyses}

All dough treatments were prepared three times. The number of analysis conducted for dough and pogaca measurements were given in the relevant section. Results were statistically analyzed with analyses of variance (One-Way ANOVA), followed by Duncan's test using SPSS, Version 11.5 (SPSS Inc., Chicago, IL). Statistical significance was indicated at a confidence level of $95 \%$.

\section{Results and discussion}

\subsection{Dough analysis}

\section{Stickiness}

Stickiness values of fat reduced formulations were generally higher than the control pogaca dough (Table 2). Only the formulations prepared by addition of $5 \mathrm{~g}$ fat replacer have statistically the same stickiness values with the control dough. Stickiness values were significantly increased $(\mathrm{p}<0.05)$ by increasing the amount of fat replacer at each fat reduction level and for all fat replacer used. In the case of using $15 \mathrm{~g}$ of inulin

Table 2. Effects of fat replacement on stickiness values of pogaca dough ${ }^{1}$.

\begin{tabular}{|c|c|c|c|c|}
\hline \multirow{2}{*}{$\begin{array}{l}\text { Rate of Fat } \\
\text { Reduction, } \\
\text { (\%) }\end{array}$} & \multirow{2}{*}{$\begin{array}{l}\text { Amount of } \\
\text { Fat Replacer, } \\
\text { (g/100g flour) }\end{array}$} & \multicolumn{3}{|c|}{ Stickiness (g) } \\
\hline & & Inulin & Maltodextrin & Polydextrose \\
\hline 0 (control) & 0 & $27.22 \pm 1.4^{\mathrm{e}}$ & $27.21 \pm 1.5^{\mathrm{f}}$ & $27.21 \pm 1.5^{\mathrm{d}, e}$ \\
\hline \multirow{3}{*}{20} & 5 & $28.33 \pm 2.0^{\mathrm{d}, \mathrm{e}}$ & $27.28 \pm 1.6^{\mathrm{f}}$ & $28.20 \pm 2.7^{\mathrm{d}}$ \\
\hline & 10 & $30.21 \pm 1.5^{\mathrm{c}, \mathrm{d}}$ & $33.20 \pm 2.2^{\mathrm{a}}$ & $31.96 \pm 2.2^{c}$ \\
\hline & 15 & $41.01 \pm 2.7^{\mathrm{a}}$ & $32.66 \pm 1.2^{\mathrm{a}, \mathrm{b}}$ & $37.15 \pm 1.7^{\mathrm{a}}$ \\
\hline \multirow{3}{*}{30} & 5 & $26.93 \pm 1.3^{\mathrm{e}}$ & $28.94 \pm 1.7^{\mathrm{d}, \mathrm{e}, \mathrm{f}}$ & $25.60 \pm 1.9^{\mathrm{d}, \mathrm{e}}$ \\
\hline & 10 & $32.02 \pm 2.8^{c}$ & $29.91 \pm 1.9^{\mathrm{cd} d}$ & $30.36 \pm 1.2^{c}$ \\
\hline & 15 & $35.26 \pm 3.4^{\mathrm{b}}$ & $32.70 \pm 1.2^{\mathrm{a}, \mathrm{b}}$ & $35.36 \pm 1.6^{\mathrm{b}}$ \\
\hline \multirow{3}{*}{40} & 5 & $28.71 \pm 4.5^{\mathrm{d}, \mathrm{e}}$ & $27.67 \pm 1.6^{\mathrm{e}, \mathrm{f}}$ & $27.21 \pm 2.4^{\mathrm{d}, \mathrm{e}}$ \\
\hline & 10 & $34.30 \pm 0.9^{b}$ & $32.66 \pm 1.8^{\mathrm{a}, \mathrm{b}}$ & $28.56 \pm 1.8^{\mathrm{d}}$ \\
\hline & 15 & $36.66 \pm 1.6^{\mathrm{b}}$ & $31.23 \pm 2.2^{\mathrm{b}, \mathrm{c}}$ & $33.95 \pm 1.4^{\mathrm{b}}$ \\
\hline
\end{tabular}

${ }^{1}$ Values are means of $\mathrm{n}=5$ measurements. \pm Standard deviation. Values within a column followed by a common letter are not significantly different $(\mathrm{P}>0.05)$. or polydextrose at all fat reduction levels, it was not possible to prepare processable dough due to the increased stickiness. Therefore, these formulations were eliminated from the study for the further analysis. The increase in stickiness with the increase in the amount of fat replacer used can be explained by the high water absorption capacity of inulin, maltodextrin or polydextrose. In a study conducted by Ghodke (2009), the stickiness of chapatti dough were also increased by the increasing the amount of guar gum added to the formulation. A number of previous studies indicated that, decreasing in the water binding capacity of gluten due to high water absorption by the ingredients used in dough formulations lead to formation of sticky structure (Dreese et al., 1988; Ghodke, 2009; O’Brien et al., 2003).

\section{Extensibility and resistance to extension}

The extensibility and resistances to extension are important rheological factors of dough that have critical effects on gas cell expansion during proofing and baking (Bloksma \& Bushuk, 1988). The extensibility and resistances to extension of the fat-reduced pogaca dough have been affected by the amount and type of the fat replacer used (Table 3). Both extensibility and resistance to extension values were significantly increased by increasing the rate of fat reduction. However, increasing the amount of fat replacer at the same fat content formulations resulted with significant decrease in the both extensibility and resistance to extension values.

Ktenioudaki \& Gallagher (2012) indicated that, the addition of different dietary fibre decreases the extensibility of dough whereas it has a variable effect on the resistance to extension. Shouk \& El-Faham (2005) found that when barley flour was used to substitute wheat flour in a croissant dough formulation, extensibility and resistance to extension decreased as barley flour level increased. These effects were attributed mainly to the dilution of gluten by the presence of barley flour.

\subsection{Pogaca analysis}

\section{Sensory analyses}

The mean scores of hedonic sensory evaluation for appearance, internal cross-sectional view, softness, stickiness, flavour and overall acceptability are given in Table 4 . There was a significant decrease in all the sensory parameters as the fat content decreased in the formulations. Sensory parameters were also decreased as the amount of fat replacer increased at the same fat content. Using $5 \mathrm{~g}$ polydextrose (on $100 \mathrm{~g}$ wheat flour basis) was the only formulation that receives statistically the same scores with the control sample at the $40 \%$ fat reduction levels. All the other formulations whose fat was reduced at the level of $40 \%$, received lower scores than the control sample from all the sensory test criteria.

Sensory analysis showed that the appearance of the pogaca samples were the least effected parameters from the fat replacement. All the formulations prepared by reducing the fat levels for 20 or $30 \%$ received statistically the same score with the control for appearance. The pogaca samples prepared from the formulations of 20 and 30\% fat reduction and using 
Table 3. Effects of fat replacement on extensibility and resistance to extension values of pogaca dough ${ }^{1}$.

\begin{tabular}{|c|c|c|c|c|c|c|c|}
\hline \multirow{2}{*}{$\begin{array}{c}\text { Rate of Fat } \\
\text { Reduction, (\%) }\end{array}$} & \multirow{2}{*}{$\begin{array}{l}\text { Amount of } \\
\text { Fat Replacer } \\
\text { (g/100g flour) }\end{array}$} & \multicolumn{3}{|c|}{ Extensibility $(\mathrm{mm})$} & \multicolumn{3}{|c|}{ Resistance of Extension(g) } \\
\hline & & Inülin & Maltodextrin & Polydextrose & Inülin & Maltodextrin & Polydextrose \\
\hline 0 (control) & 0 & $10.5 \pm 1.3^{\mathrm{d}}$ & $10.5 \pm 1.3^{\mathrm{f}}$ & $10.5 \pm 1.3^{c}$ & $16.6 \pm 2.9^{\mathrm{d}}$ & $16.6 \pm 2.9^{f}$ & $16.6 \pm 2.9^{e}$ \\
\hline \multirow[t]{2}{*}{20} & 10 & $11.4 \pm 1.8^{\mathrm{d}}$ & $13.3 \pm 1.6^{\mathrm{e}}$ & $11.3 \pm 0.9^{c}$ & $15.3 \pm 1.6^{\mathrm{d}}$ & $13.6 \pm 1.5^{g}$ & $13.5 \pm 0.8^{\mathrm{f}}$ \\
\hline & 15 & $\mathrm{nd}^{2}$ & $11.4 \pm 1.7^{\mathrm{f}}$ & nd & nd & $12.6 \pm 1.4^{\mathrm{g}}$ & nd \\
\hline \multirow{2}{*}{30} & 5 & $15.3 \pm 2.6^{\mathrm{b}}$ & $16.2 \pm 1.8^{\mathrm{a}, \mathrm{b}}$ & $16.2 \pm 1.6^{\mathrm{a}}$ & $23.0 \pm 4.9^{\mathrm{b}, \mathrm{c}}$ & $24.8 \pm 2.2^{\mathrm{c}}$ & $36.7 \pm 5.2^{\mathrm{b}}$ \\
\hline & 15 & nd & $14.3 \pm 1.2^{\mathrm{d}, \mathrm{e}}$ & nd & nd & $22.3 \pm 1.2^{\mathrm{d}, \mathrm{e}}$ & nd \\
\hline \multirow{3}{*}{40} & 5 & $16.9 \pm 1.8^{\mathrm{a}}$ & $15.2 \pm 2.1^{\mathrm{b}, \mathrm{c}, \mathrm{d}}$ & $15.6 \pm 1.6^{\mathrm{a}}$ & $43.5 \pm 7.67^{\mathrm{a}}$ & $33.6 \pm 5.0^{\mathrm{a}}$ & $48.0 \pm 2.8^{\mathrm{a}}$ \\
\hline & 10 & $15.9 \pm 2.2^{\mathrm{a}, \mathrm{b}}$ & $15.9 \pm 2.5^{\mathrm{a}, \mathrm{b}, \mathrm{c}}$ & $15.8 \pm 2.2^{\mathrm{a}}$ & $19.5 \pm 2.5^{\mathrm{b}, \mathrm{c}}$ & $29.3 \pm 4.4^{\mathrm{b}}$ & $19.5 \pm 2.5^{\mathrm{d}}$ \\
\hline & 15 & nd & $16.7 \pm 1.3^{\mathrm{a}}$ & nd & nd & $23.6 \pm 3.2^{\mathrm{c}, \mathrm{d}}$ & nd \\
\hline
\end{tabular}

${ }^{1}$ Values are means of $\mathrm{n}=5$ measurements. \pm Standard deviation. Values within a column followed by a common letter are not significantly different $(\mathrm{P}>0.05)$. ${ }^{2} \mathrm{This}$ formulations were eliminated since they were non-processable due to high stickiness.

Table 4. Effects of fat replacement on sensory characteristics of pogaca ${ }^{1}$.

\begin{tabular}{|c|c|c|c|c|c|c|c|c|}
\hline $\begin{array}{c}\text { Fat } \\
\text { replacer }\end{array}$ & $\begin{array}{c}\text { Rate of } \\
\text { Reduced } \\
\text { Fat (\%) }\end{array}$ & $\begin{array}{l}\text { Amount of } \\
\text { Fat Replacer } \\
\text { (g/100 g flour) }\end{array}$ & Appearance & $\begin{array}{c}\text { Internal } \\
\text { cross-sectional } \\
\text { view }\end{array}$ & Softness & Stickiness & Flavor & $\begin{array}{c}\text { Overall } \\
\text { Acceptability }\end{array}$ \\
\hline & Control & 0 & $3.8 \pm 0.4^{\mathrm{a}, \mathrm{b}, \mathrm{c}, \mathrm{d}}$ & $3.6 \pm 0.4^{\mathrm{a}, \mathrm{b}, \mathrm{c}, \mathrm{d}}$ & $3.6 \pm 0.3^{\mathrm{a}}$ & $4.3 \pm 0.5^{\mathrm{a}, \mathrm{b}, \mathrm{c}}$ & $3.7 \pm 0.4^{\mathrm{a}, \mathrm{b}}$ & $3.4 \pm 0.4^{\mathrm{a}, \mathrm{b}, \mathrm{c}, \mathrm{d}}$ \\
\hline \multirow{6}{*}{$\stackrel{\Xi \Xi}{\Xi}$} & \multirow{2}{*}{20} & 5 & $3.6 \pm 0.7^{\mathrm{a}, \mathrm{b}, \mathrm{c}, \mathrm{d}}$ & $3.4 \pm 0.8^{\mathrm{a}, \mathrm{b}, \mathrm{c}, \mathrm{d}, \mathrm{e}}$ & $3.2 \pm 0.9^{\mathrm{a}, \mathrm{b}, \mathrm{c}, \mathrm{d}}$ & $2.8 \pm 1.2^{\mathrm{a}, \mathrm{b}, \mathrm{c}, \mathrm{d}, \mathrm{e}}$ & $3.3 \pm 1.3^{\mathrm{a}, \mathrm{b}, \mathrm{c}}$ & $3.2 \pm 0.7^{\mathrm{a}, \mathrm{b}, \mathrm{b}, \mathrm{d}, \mathrm{e}, \mathrm{f}, \mathrm{g}}$ \\
\hline & & 10 & $3.2 \pm 1.0^{\mathrm{a}, \mathrm{b}, \mathrm{c}, \mathrm{d}, \mathrm{e}}$ & $2.6 \pm 0.7^{\text {d,e,f }}$ & $2.9 \pm 0.9^{\mathrm{a}, \mathrm{b}, \mathrm{c}, \mathrm{d}, \mathrm{e}}$ & $2.7 \pm 0.8^{\text {b,c,d,e }}$ & $3.4 \pm 0.8^{\mathrm{a}, \mathrm{b}, \mathrm{c}}$ & $3.0 \pm 0.6^{\mathrm{a}, \mathrm{b}, \mathrm{b}, \mathrm{d}, \mathrm{e}, \mathrm{f}, \mathrm{g}}$ \\
\hline & \multirow{2}{*}{30} & 5 & $3.5 \pm 0.8^{\mathrm{a}, \mathrm{b}, \mathrm{c}, \mathrm{d}, \mathrm{e}}$ & $3.0 \pm 0.8^{\text {c,d,e,f }}$ & $2.3 \pm 0.8^{\mathrm{d}, \mathrm{e}, \mathrm{f}}$ & $3.1 \pm 0.8^{\mathrm{a}, \mathrm{b}, \mathrm{c}, \mathrm{d}}$ & $3.2 \pm 1.1^{\mathrm{a}, \mathrm{b}, \mathrm{c}}$ & $3.0 \pm 0.7^{\mathrm{a}, \mathrm{b}, \mathrm{c}, \mathrm{d}, \mathrm{e}, \mathrm{f}, \mathrm{g}}$ \\
\hline & & 10 & $3.5 \pm 1.0^{\mathrm{a}, \mathrm{b}, \mathrm{c}, \mathrm{d}, \mathrm{e}}$ & $2.4 \pm 1.0^{\mathrm{e}, \mathrm{f}}$ & $2.1 \pm 0.8^{\mathrm{e}, \mathrm{f}}$ & $2.6 \pm 0.9^{\mathrm{b}, c, \mathrm{~d}, \mathrm{e}}$ & $3.3 \pm 1.2^{\mathrm{a}, \mathrm{b}, \mathrm{c}}$ & $2.8 \pm 1.2^{\mathrm{b}, c, \mathrm{~d}, \mathrm{e}, \mathrm{f}, \mathrm{g}}$ \\
\hline & \multirow{2}{*}{40} & 5 & $2.7 \pm 0.9^{\mathrm{c}, \mathrm{d}, \mathrm{e}}$ & $2.4 \pm 1.2^{\mathrm{e}}$ & $1.6 \pm 1.3^{\mathrm{f}, \mathrm{g}}$ & $2.0 \pm 1.4^{\mathrm{d}, \mathrm{e}, \mathrm{f}}$ & $2.6 \pm 1.3^{\mathrm{b}, \mathrm{c}, \mathrm{d}}$ & $2.1 \pm 1.1^{\mathrm{g}, \mathrm{h}}$ \\
\hline & & 10 & $1.5 \pm 0.8^{\mathrm{f}}$ & $1.1 \pm 0.7^{\mathrm{g}}$ & $1.0 \pm 0.4^{\mathrm{g}}$ & $1.3 \pm 0.9^{\mathrm{f}}$ & $1.8 \pm 0.9^{\mathrm{d}}$ & $1.3 \pm 0.8^{\mathrm{h}}$ \\
\hline \multirow{9}{*}{ 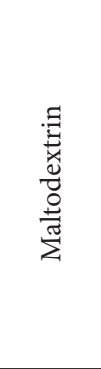 } & \multirow{3}{*}{20} & 5 & $4.3 \pm 0.5^{\mathrm{a}}$ & $4.2 \pm 0.7^{\mathrm{a}}$ & $3.6 \pm 1.2^{\mathrm{a}}$ & $3.9 \pm 1.1^{\mathrm{a}}$ & $4.1 \pm 1.3^{\mathrm{a}}$ & $4.0 \pm 1.3^{\mathrm{a}}$ \\
\hline & & 10 & $3.8 \pm 0.5^{\mathrm{a}, \mathrm{b}, \mathrm{c}}$ & $3.6 \pm 0.8^{\mathrm{a}, \mathrm{b}, \mathrm{c}}$ & $3.7 \pm 0.5^{\mathrm{a}}$ & $2.5 \pm 1.2^{\mathrm{b}, \mathrm{c}, \mathrm{d}, \mathrm{e}}$ & $3.5 \pm 0.5^{\mathrm{a}, \mathrm{b}}$ & $3.3 \pm 0.9^{\mathrm{a}, \mathrm{b}, \mathrm{c}, \mathrm{d}, \mathrm{e}, \mathrm{f}}$ \\
\hline & & 15 & $3.2 \pm 1.2^{\mathrm{a}, \mathrm{b}, \mathrm{c}, \mathrm{d}, \mathrm{e}}$ & $3.1 \pm 0.9^{\mathrm{b}, \mathrm{c}, \mathrm{d}, \mathrm{e}}$ & $2.5 \pm 1.0^{\mathrm{b}, \mathrm{c}, \mathrm{d}, \mathrm{e}}$ & $1.9 \pm 1.1^{\mathrm{d}, \mathrm{e}, \mathrm{f}}$ & $2.9 \pm 0.7^{\mathrm{b}, \mathrm{c}}$ & $2.8 \pm 0.9^{\mathrm{b}, c, \mathrm{~d}, \mathrm{e}, \mathrm{f}, \mathrm{g}}$ \\
\hline & \multirow{3}{*}{30} & 5 & $4.2 \pm 0.9^{\mathrm{a}, \mathrm{b}}$ & $4.1 \pm 0.6^{\mathrm{a}, \mathrm{b}}$ & $3.2 \pm 1.0^{\mathrm{a}, \mathrm{b}, \mathrm{c}, \mathrm{d}}$ & $3.6 \pm 1.2^{\mathrm{a}, \mathrm{b}}$ & $3.7 \pm 0.8^{\mathrm{a}, \mathrm{b}}$ & $3.8 \pm 0.7^{\mathrm{a}, \mathrm{b}, \mathrm{c}}$ \\
\hline & & 10 & $3.2 \pm 0.6^{\mathrm{a}, \mathrm{b}, \mathrm{c}, \mathrm{d}, \mathrm{e}}$ & $3.4 \pm 0.7^{\mathrm{a}, \mathrm{b}, \mathrm{c}, \mathrm{d}, \mathrm{e}}$ & $3.2 \pm 0.6^{\mathrm{a}, \mathrm{b}, \mathrm{c}, \mathrm{d}}$ & $2.4 \pm 0.8^{\mathrm{b}, \mathrm{c}, \mathrm{d}, \mathrm{e}, \mathrm{f}}$ & $2.7 \pm 0.7^{\mathrm{b}, c, \mathrm{~d}}$ & $2.7 \pm 0.4^{\mathrm{c}, \mathrm{d}, \mathrm{e}, \mathrm{f}, \mathrm{g}}$ \\
\hline & & 15 & $3.0 \pm 1.2^{\mathrm{b}, \mathrm{c}, \mathrm{d}, \mathrm{e}}$ & $3.3 \pm 0.8^{\mathrm{a}, \mathrm{b}, \mathrm{c}, \mathrm{d}, \mathrm{e}}$ & $2.9 \pm 0.8^{\mathrm{a}, \mathrm{b}, \mathrm{c}, \mathrm{d}, \mathrm{e}}$ & $2.3 \pm 0.8^{\mathrm{c}, \mathrm{d}, \mathrm{e}, \mathrm{f}}$ & $3.0 \pm 1.1^{\mathrm{a}, \mathrm{b}, \mathrm{c}}$ & $2.8 \pm 1.2^{\mathrm{b}, c, \mathrm{~d}, \mathrm{e}, \mathrm{f}, \mathrm{g}}$ \\
\hline & \multirow{3}{*}{40} & 5 & $2.7 \pm 1.1^{\mathrm{c}, \mathrm{d}, \mathrm{e}}$ & $3.7 \pm 0.9^{\mathrm{a}, \mathrm{b}, \mathrm{c}}$ & $3.2 \pm 0.6^{\mathrm{a}, \mathrm{b}, \mathrm{c}, \mathrm{d}}$ & $1.9 \pm 0.6^{\mathrm{e}, \mathrm{f}}$ & $2.3 \pm 0.8^{\mathrm{cd} d}$ & $2.6 \pm 1.0^{\mathrm{d}, \mathrm{e}, \mathrm{f}, \mathrm{g}}$ \\
\hline & & 10 & $2.7 \pm 1.2^{\mathrm{c}, \mathrm{d}, \mathrm{e}}$ & $2.7 \pm 0.9^{\text {c,d,e,f }}$ & $2.8 \pm 0.7^{\mathrm{a}, \mathrm{b}, \mathrm{c}, \mathrm{d}, \mathrm{e}}$ & $2.2 \pm 1.0^{\text {c,d,e,f }}$ & $2.6 \pm 0.4^{\mathrm{b}, c, \mathrm{~d}}$ & $2.5 \pm 0.8^{\mathrm{e}, \mathrm{f}, \mathrm{g}}$ \\
\hline & & 15 & $2.3 \pm 1.3^{\mathrm{e}, \mathrm{f}}$ & $2.0 \pm 1.1^{e, f}$ & $2.5 \pm 0.9^{\mathrm{b}, \mathrm{c}, \mathrm{d}, \mathrm{e}}$ & $2.0 \pm 1.1^{\mathrm{d}, \mathrm{e}, \mathrm{f}}$ & $2.7 \pm 1.0^{\mathrm{b}, c, \mathrm{~d}}$ & $2.2 \pm 0.8^{\mathrm{fg}, \mathrm{h}}$ \\
\hline \multirow{6}{*}{ 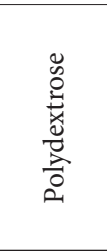 } & \multirow{2}{*}{20} & 5 & $4.0 \pm 0.5^{\mathrm{a}, \mathrm{b}}$ & $4.1 \pm 0.5^{\mathrm{a}, \mathrm{b}}$ & $3.6 \pm 0.5^{\mathrm{a}}$ & $2.8 \pm 1.2^{\mathrm{a}, \mathrm{b}, \mathrm{c}, \mathrm{d}, \mathrm{e}}$ & $3.8 \pm 0.9^{\mathrm{a}, \mathrm{b}}$ & $3.8 \pm 0.9^{\mathrm{a}, \mathrm{b}}$ \\
\hline & & 10 & $3.2 \pm 1.2^{\mathrm{a}, \mathrm{b}, \mathrm{c}, \mathrm{d}, \mathrm{e}}$ & $3.5 \pm 0.8^{\mathrm{a}, \mathrm{b}, \mathrm{c}, \mathrm{d}}$ & $3.5 \pm 0.7^{\mathrm{a}, \mathrm{b}}$ & $3.3 \pm 0.8^{\mathrm{a}, \mathrm{b}, \mathrm{c}}$ & $3.7 \pm 1.0^{\mathrm{a}, \mathrm{b}}$ & $3.6 \pm 0.9^{\mathrm{a}, \mathrm{b}, \mathrm{c}, \mathrm{d}, \mathrm{e}}$ \\
\hline & \multirow{2}{*}{30} & 5 & $3.1 \pm 1.6^{\mathrm{a}, \mathrm{b}, \mathrm{c}, \mathrm{d}, \mathrm{e}}$ & $3.2 \pm 1.4^{\mathrm{a}, \mathrm{b}, \mathrm{c}, \mathrm{d}, \mathrm{e}}$ & $2.9 \pm 0.5^{\mathrm{a}, \mathrm{b}, \mathrm{c}, \mathrm{d}, \mathrm{e}}$ & $2.7 \pm 0.8^{\mathrm{b}, \mathrm{c}, \mathrm{d}, \mathrm{e}}$ & $3.6 \pm 1.1^{\mathrm{a}, \mathrm{b}}$ & $3.5 \pm 1.0^{\mathrm{a}, \mathrm{b}, \mathrm{c}, \mathrm{d}, \mathrm{e}}$ \\
\hline & & 10 & $3.2 \pm 1.6^{\mathrm{a}, \mathrm{b}, \mathrm{c}, \mathrm{d}, \mathrm{e}}$ & $2.8 \pm 1.3^{c, d, e, f}$ & $2.5 \pm 1.2^{\mathrm{c}, \mathrm{d}, \mathrm{e}, \mathrm{f}}$ & $3.0 \pm 1.1^{\mathrm{a}, \mathrm{b}, \mathrm{c}, \mathrm{d}, \mathrm{e}}$ & $3.3 \pm 1.4^{\mathrm{a}, \mathrm{b}, \mathrm{c}}$ & $3.2 \pm 1.4^{\mathrm{a}, \mathrm{b}, \mathrm{c}, \mathrm{d}, \mathrm{e}, \mathrm{f}}$ \\
\hline & \multirow{2}{*}{40} & 5 & $3.4 \pm 1.0^{\mathrm{a}, \mathrm{b}, \mathrm{c}, \mathrm{d}, \mathrm{e}}$ & $3.6 \pm 0.9^{\mathrm{a}, \mathrm{b}, \mathrm{c}}$ & $3.3 \pm 0.5^{\mathrm{a}, \mathrm{b}, \mathrm{c}}$ & $3.4 \pm 1.0^{\mathrm{a}, \mathrm{b}, \mathrm{c}}$ & $3.5 \pm 0.8^{\mathrm{a}, \mathrm{b}}$ & $3.5 \pm 0.9^{\mathrm{a}, \mathrm{b}, \mathrm{c}, \mathrm{d}, \mathrm{e}}$ \\
\hline & & 10 & $2.5 \pm 1.4^{\mathrm{d}, \mathrm{e}}$ & $2.6 \pm 0.7^{\mathrm{d}, e, f}$ & $2.6 \pm 0.7^{\mathrm{b}, \mathrm{c}, \mathrm{d}, \mathrm{e}}$ & $3.0 \pm 0.9^{\mathrm{a}, \mathrm{b}, \mathrm{c}, \mathrm{d}, \mathrm{e}}$ & $2.9 \pm 0.5^{\mathrm{b}, \mathrm{c}}$ & $2.7 \pm 0.9^{\mathrm{b}, c, \mathrm{~d}, \mathrm{e}, \mathrm{f}, \mathrm{g}}$ \\
\hline
\end{tabular}

${ }^{1}$ Values are means of $\mathrm{n}=10$ measurements. \pm Standard deviation. Values within a column followed by a common letter are not significantly different (P $\left.>0.05\right)$.

$5 \mathrm{~g}$ maltodextrin received the highest scores in terms of internal cross-sectional view. The increase in fat reduction level and the amount of fat replacer used resulted with significant decrease in the internal cross-sectional view scores except for the sample were the fat reduced by $40 \%$ and replaced by 5 and $10 \mathrm{~g}$ polydextrose. This might be attributed to the decrease in the average pore size uniformity of the crust. Reduction in the average pore size uniformity was also obtained in the crust of the reduced fat cake (Kocer et al., 2007). Softness is another important sensory parameter of pogaca quality. The increase in fat reduction level were also decreased the sensory scores of softness. Drastic decrease in softness values were observed in the replacement of fat by increasing the amount of inulin. The reductions in softness scores were not as much as high in the case of using maltodextrin or polydextrose. It was stated that inulin integrates well to the gluten network and dilutes it, which caused lower gas retention ability (Morris \& Morris, 2012). Correspondingly, inner density of pogaca sample with inulin was increased and therefore the crumb hardness increased. In the case of stickiness, the samples prepared by using inulin and maltodextrin as fat replacer at $40 \%$ fat reduction rate received significantly lower scores than control, except for the rate of reduced fat $40 \%$ and amount of fat 
replacer was $10 \mathrm{~g} / 100 \mathrm{~g}$ flour. Generally the flavour and overall acceptability received similar sensory scores. The flavour and overall acceptability scores of the samples prepared by using inulin and maltodextrin as the fat replacer at $40 \%$ fat reduction received lower scores than the control samples. The sensory analysis results showed that increasing the rate of fat replacement had negative effects on the sensory properties of the pogaca. In a previous study in the literature, it was also stated that, increasing the amount of fat replacer in a muffin formulation resulted with significant decrease in the sensory properties of muffins (Zahn et al., 2010). It was expressed that; this might have been related to a significant increase in the humidity and inner density of the product, along with the increase in the amount of fat replacer, and with the decrease in the product volume (Zahn et al., 2010).

According to the results of sensory analysis, formulations with the addition of fat replacer that had received statistically the same $(\mathrm{P}>0.05)$ results with the control sample in all the parameters were chosen. The further quality parameters analyses of pogaca were conducted only on these formulations. The only formulation, which received statistically the same scores from all the sensory parameters at $40 \%$ fat reduction rate, was the one using $5 \mathrm{~g}$ polydextrose as fat replacer.

\section{Firmness}

Firmness of pogaca samples are given in Table 5. Firmness were tended to increase along with the decrease in fat content and also with the increase in the amount of fat replacers used. Drastic increase in pogaca firmness were observed in the case of the increasing the amount of inulin used at $20 \%$ fat reduction rate. Firmness values of the all samples prepared by using the maltodextrin as fat replacer were similar to the control sample, except for $30 \%$ rate of fat reduction and $15 \mathrm{~g}$ of maltodextrin addition. This might be explained by the moisture holding properties of maltodextrin, which was able to provide the same softness properties with the fat in the formulations. In the case of using polydextrose as fat replacer, firmness values were higher than the firmness of control sample. Previous studies in the literature were also indicated that the substitution of fat with carbohydrate based fat replacers caused harder texture in the bakery products (Grigelmo-Miguel et al., 2001; Khouryieh et al., 2005; Zahn et al., 2010; Zoulias et al., 2002). Lee et al. (2008) stated that, tiny air bubbles were detained in the fat during dough preparation. Those air bubbles expanded during baking stage and caused the dough to spread and to provide a soft texture. Therefore, the reduction in fat content limits this mechanism and resulted with harder texture in bakery products.

\section{Crumb and crust colour}

The visual appearance of a food product is one of the most important determinants of acceptance by the consumers. The $\mathrm{L}^{\star}$ (lightness) values of the crumb section of all the formulations were similar to the control (Table 6), indicating that the fat replacers has minimum effect on the darkening of the crumb section of pogaca. The results indicated that the increase in fat reduction rate and the amount of fat replacer used resulted with lower crumb redness $\left(\mathrm{a}^{*}\right)$ values. There were no statistically significant differences between the crumb yellowness $\left(b^{*}\right)$ values of fat reduced formulations and the control.
Table 5. Effects of fat replacement on firmness of pogaca ${ }^{1}$.

\begin{tabular}{|c|c|c|c|}
\hline $\begin{array}{c}\text { Fat } \\
\text { replacer }\end{array}$ & $\begin{array}{l}\text { Rate of fat } \\
\text { reduction } \\
(\%)\end{array}$ & $\begin{array}{l}\text { Amount of fat } \\
\text { replacer used } \\
\text { (g/100g flour) }\end{array}$ & $\begin{array}{l}\text { Firmness } \\
\quad(\mathrm{g})\end{array}$ \\
\hline & $\begin{array}{c}0 \\
\text { (Control) }\end{array}$ & 0 & $613.96 \pm 81.0^{\mathrm{f}}$ \\
\hline \multirow{2}{*}{$\stackrel{. \Xi}{\Xi}$} & \multirow{2}{*}{20} & 5 & $598.94 \pm 85.6^{\mathrm{f}}$ \\
\hline & & 10 & $1303.5 \pm 174.6^{a}$ \\
\hline \multirow{5}{*}{ 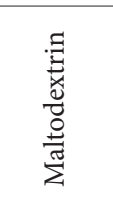 } & \multirow{2}{*}{20} & 5 & $639.22 \pm 77.3^{\mathrm{f}}$ \\
\hline & & 10 & $664.27 \pm 123.1^{\mathrm{e}, \mathrm{f}}$ \\
\hline & \multirow{3}{*}{30} & 5 & $624.77 \pm 56.2^{\mathrm{f}}$ \\
\hline & & 10 & $697.60 \pm 98.0^{\mathrm{e}, \mathrm{f}}$ \\
\hline & & 15 & $884.44 \pm 140.6^{\mathrm{b}, \mathrm{c}}$ \\
\hline \multirow{4}{*}{ 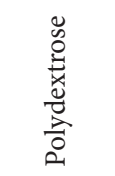 } & \multirow{2}{*}{20} & 5 & $792.61 \pm 110.4^{c, d}$ \\
\hline & & 10 & $881.97 \pm 204.0^{\mathrm{b}, \mathrm{c}}$ \\
\hline & 30 & 5 & $750.39 \pm 84.8^{\mathrm{d}, \mathrm{e}}$ \\
\hline & 40 & 5 & $943.42 \pm 121.0^{b}$ \\
\hline
\end{tabular}

${ }^{1}$ Values are means of $n=15$ measurements. \pm Standard deviation. Values within a column followed by a common letter are not significantly different $(\mathrm{P}>0.05)$.

In the case of crust colour, the formulations prepared by addition of $5 \mathrm{~g}$ fat replacer at each fat reduction level and for all fat replacer used have statistically the same $L$ values with the control pogaca. However, the increase in the amount of fat replacer used, at the same fat reduction rate and for all the type of fat replacers, resulted with significant increase in the $L$ values. This increase in lightness might be due to the decrease in the browning reactions occurs at surface of the pogaca samples. Incorporation of different dietary fibre samples into bread formulations were also increased the lightness of bread crust (Feili et al., 2013; Gómez et al., 2003). There were no significant changes in the crust redness for the most of the fat reduced pogaca samples. However, yellowness $\left(b^{*}\right)$ of the fat reduced samples were tended to be higher than the control samples. This might be explained by the low amounts of reducing sugars in the composition of fat replacers, which increase the formation of coloured Maillard or caramelization reaction products (Purlis, 2010). Brown crust colour in consequence of the browning reaction in the cake samples were observed as the level of carbohydrate based fat replacers increased from $25 \%$ to $50 \%$ and $75 \%$ (Khalil, 1998). Same results were observed in other studies carried out in the literature (Sanchez et al., 1995; Conforti et al., 1997; Morris \& Morris, 2012). On the contrary, in fat-reduced pogaca samples in the current study, the crust colour got lighter as the rate of replacer increased. This might be related to the crack formation on the surface of pogaca, which may reduce the perception of colour intensity. In addition to that the thickness/amount of egg yolk, used for covering the surface of pogaca, is another factor on the colour intensity on the surface. However, all the samples were covered with the same method and the same amount to eliminate the effect of egg yolk in this study.

\section{Moisture content and volume}

Moisture content and volume of pogaca have significant effect on the sensory quality of the bakery products. The moisture contents of the fat reduced pogaca samples were similar to the control sample (Table 7). There were also no drastic changes in the volume of the pogaca samples where $5 \mathrm{~g}$ fat replacer used 
Table 6. Effects of fat replacement on crust and crumb colour of pogaca ${ }^{1}$.

\begin{tabular}{|c|c|c|c|c|c|c|c|c|}
\hline \multirow{2}{*}{$\begin{array}{l}\text { Type of Fat } \\
\text { Replacer }\end{array}$} & \multirow{2}{*}{$\begin{array}{c}\text { Rate of Fat } \\
\text { Reduction } \\
\quad(\%)\end{array}$} & \multirow{2}{*}{$\begin{array}{c}\text { Amount of Fat } \\
\text { Replacer } \\
(\mathrm{g} / 100 \mathrm{~g})\end{array}$} & \multicolumn{3}{|c|}{ Crumb } & \multicolumn{3}{|c|}{ Crust } \\
\hline & & & $\mathrm{L}^{*}$ & $a^{*}$ & $b^{*}$ & $\mathrm{~L}^{*}$ & $a^{*}$ & $b^{*}$ \\
\hline & Control & 0 & $78.12 \pm 2.9^{\mathrm{d}, \mathrm{e}}$ & $6.54 \pm 1.9^{c, \mathrm{~d}}$ & $31.17 \pm 1.4^{\mathrm{a}, \mathrm{b}}$ & $41.28 \pm 4.9^{g, h}$ & $27.17 \pm 3.8^{\mathrm{b}, \mathrm{c}}$ & $19.35 \pm 5.8^{\mathrm{d}}$ \\
\hline \multirow{2}{*}{$\stackrel{\Xi}{\Xi}$} & \multirow{2}{*}{20} & 5 & $76.13 \pm 2.2^{\mathrm{e}}$ & $7.33 \pm 0.8^{\mathrm{b}, \mathrm{c}}$ & $31.26 \pm 1.3^{\mathrm{a}, \mathrm{b}}$ & $47.19 \pm 6.7^{7^{\mathrm{f}, \mathrm{g}}}$ & $28.62 \pm 3.8^{\mathrm{b}, \mathrm{c}}$ & $28.42 \pm 7.7^{\mathrm{b}, \mathrm{c}}$ \\
\hline & & 10 & $82.00 \pm 0.4^{\mathrm{b}, \mathrm{c}}$ & $4.71 \pm 0.4^{\mathrm{d}, \mathrm{e}}$ & $32.30 \pm 0.5^{\mathrm{b}}$ & $52.25 \pm 1.4^{\mathrm{d}, \mathrm{e}}$ & $39.56 \pm 1.2^{\mathrm{a}}$ & $30.41 \pm 2.4^{\mathrm{b}, \mathrm{c}}$ \\
\hline \multirow{5}{*}{ 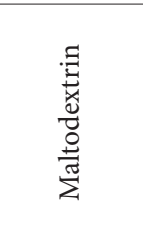 } & \multirow{2}{*}{20} & 5 & $79.92 \pm 1.6^{\mathrm{c}, \mathrm{d}}$ & $7.14 \pm 0.9^{\mathrm{b}, \mathrm{c}}$ & $31.27 \pm 1.5^{\mathrm{a}, \mathrm{b}}$ & $39.64 \pm 3.9^{\mathrm{h}}$ & $28.42 \pm 2.9^{b, c}$ & $19.39 \pm 5.0^{\mathrm{d}}$ \\
\hline & & 10 & $81.61 \pm 1.3^{\mathrm{b}, \mathrm{c}}$ & $3.57 \pm 1.1^{\mathrm{e}, \mathrm{f}}$ & $32.60 \pm 2.8^{\mathrm{b}}$ & $59.60 \pm 7.8^{\mathrm{b}, \mathrm{c}}$ & $30.76 \pm 5.8^{b}$ & $42.57 \pm 8.0^{\mathrm{a}}$ \\
\hline & \multirow{3}{*}{30} & 5 & $80.80 \pm 1.9^{c, d}$ & $4.16 \pm 1.2^{\mathrm{e}}$ & $29.43 \pm 1.5^{\mathrm{a}}$ & $46.75 \pm 7.4^{\mathrm{e}, \mathrm{f}, \mathrm{g}}$ & $29.57 \pm 5.1^{\mathrm{b}, \mathrm{c}}$ & $25.79 \pm 8.9^{c}$ \\
\hline & & 10 & $80.62 \pm 2.2^{\mathrm{c,d}}$ & $5.58 \pm 2.7^{\mathrm{c}, \mathrm{d}, \mathrm{e}}$ & $29.64 \pm 0.9^{\mathrm{a}}$ & $62.97 \pm 5.0^{\mathrm{b}}$ & $30.20 \pm 6.0^{\mathrm{b}}$ & $43.95 \pm 3.3^{\mathrm{a}}$ \\
\hline & & 15 & $83.81 \pm 2.52^{\mathrm{b}}$ & $1.67 \pm 2.2^{\mathrm{f}}$ & $31.80 \pm 0.8^{\mathrm{b}}$ & $71.64 \pm 2.5^{\mathrm{a}}$ & $19.35 \pm 4.6^{\mathrm{d}}$ & $48.42 \pm 1.6^{\mathrm{a}}$ \\
\hline \multirow{4}{*}{ 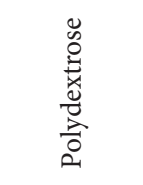 } & \multirow{2}{*}{20} & 5 & $75.65 \pm 2.9^{\mathrm{e}}$ & $11.39 \pm 1.5^{\mathrm{a}}$ & $30.55 \pm 1.9^{\mathrm{a}, \mathrm{b}}$ & $38.17 \pm 6.2^{\mathrm{h}}$ & $24.71 \pm 3.5^{c}$ & $16.56 \pm 7.0^{\mathrm{d}}$ \\
\hline & & 10 & $76.44 \pm 3.4^{e}$ & $8.75 \pm 2.3^{\mathrm{b}}$ & $31.26 \pm 2.4^{\mathrm{a}, \mathrm{b}}$ & $54.70 \pm 6.3^{\mathrm{c}, \mathrm{d}}$ & $29.64 \pm 1.9^{\mathrm{b}}$ & $34.39 \pm 6.3^{b}$ \\
\hline & 30 & 5 & $81.01 \pm 2.4^{\mathrm{b}, \mathrm{c} d \mathrm{~d}}$ & $3.90 \pm 1.8^{\mathrm{e}}$ & $31.04 \pm 0.8^{\mathrm{a}, \mathrm{b}}$ & $48.41 \pm 4.9^{e^{e, f g}}$ & $29.04 \pm 2.7^{\mathrm{b}, \mathrm{c}}$ & $29.70 \pm 4.2^{\mathrm{b}, \mathrm{c}}$ \\
\hline & 40 & 5 & $80.76 \pm 1.9^{c, d}$ & $3.79 \pm 1.2^{\mathrm{e}}$ & $31.17 \pm 1.2^{\mathrm{a}, \mathrm{b}}$ & $45.87 \pm 4.5^{\mathrm{f}, \mathrm{g}}$ & $27.60 \pm 1.7^{\mathrm{b}, \mathrm{c}}$ & $26.34 \pm 5.0^{c}$ \\
\hline
\end{tabular}

${ }^{1}$ Values are means of $\mathrm{n}=6$ measurements. \pm Standard deviation. Values within a column followed by a common letter are not significantly different $(\mathrm{P}>0.05)$.

Table 7. Effect of fat replacement on moisture content and volume of pogaca ${ }^{1}$.

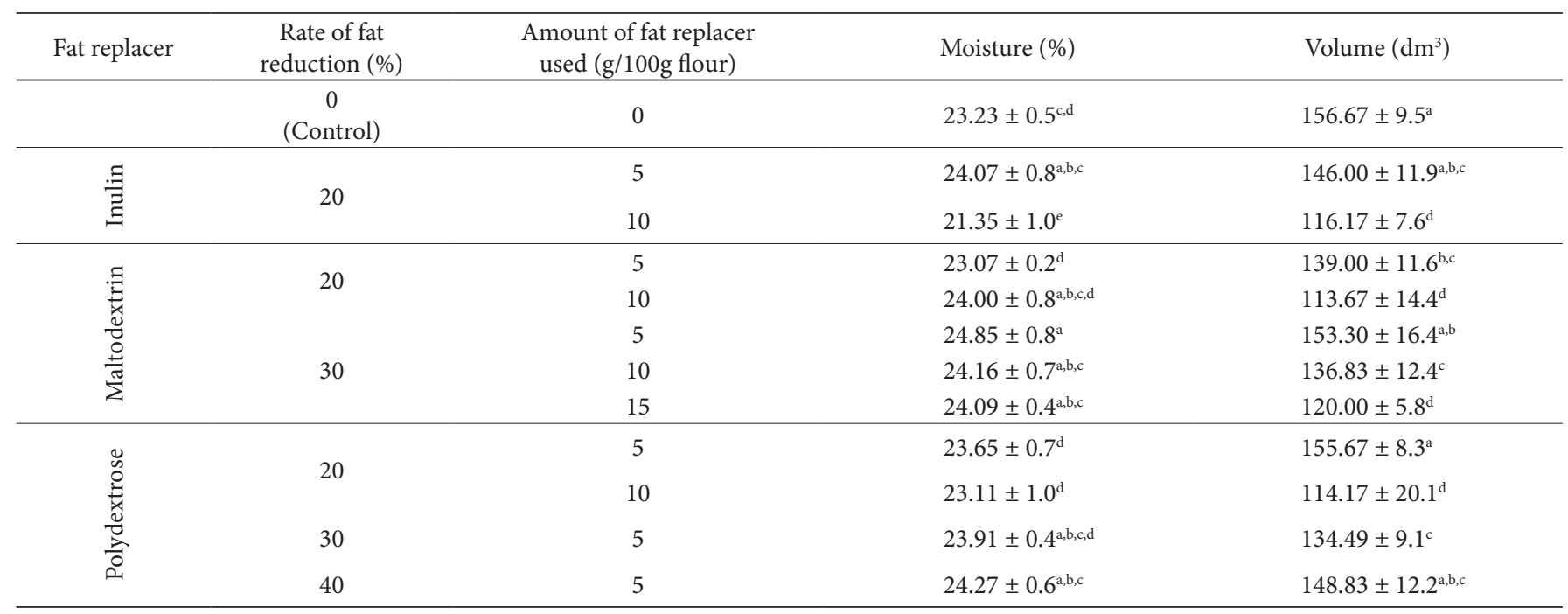

${ }^{1}$ Values are means of $\mathrm{n}=6$ measurements, \pm standard deviation. Values within a column followed by a common letter are not significantly different $(\mathrm{P}>0.05)$.

for each fat reduction level. However, increasing the amount of fat replacer at the same fat reduction level caused to significant decrease in the volume of the products. Replacement of fat with carbohydrate based fat replacers in muffins and cakes were also resulted with lower volume products compared with the control samples (Lakshminarayan et al., 2006; Kocer et al., 2007; Zahn et al., 2010). This might be explained by two possible mechanisms. The first one is the increasing amount of fat replacers used in the formulations may lead to the gluten dilution, which affect the optimal gluten matrix formation during the mixing, fermentation and baking steps (Feili et al., 2013). The second possible mechanism is the decrease in the amount of air bubbles, which incorporated into the dough during mixing and expand during baking (Zahn et al., 2010). In another study conducted by Bath et al. (1992), it was also indicated that the decrease in fat content caused to lower volume in high ratio layer cakes.

\section{Conclusion}

The increase in the fat replacement rate (decrease in fat content) has no significant effect on the stickiness of pogaca dough if the amount of fat replacer does not exceed the $5 \mathrm{~g} / 100 \mathrm{~g}$ wheat flour in the formula. However, the increase of the fat replacer amount from 5 to 10 or $15 \mathrm{~g} / 100 \mathrm{~g}$ wheat flour basis has drastic increase in the dough stickiness. The results from this study were also showed that it was possible to arrange a certain formulation to produce pogaca dough with the similar extensibility and resistance to extension values with the control dough. The increased reduction in fat content of pogaca formulations resulted with significant decrease in softness, which is the most important quality characteristic of pogaca. Interpretations of the whole findings in this study showed that up to $30 \%$ of the fat in pogaca can be replaced by maltodextrin and polydextrose as fat replacer with non-significant change in the dough characteristic 
and the quality of the baked pogaca. This $30 \%$ fat reduction in pogaca formulation corresponds to around $22 \%$ reduction in the total calories of the products. More detailed studies on the formula optimization is needed to reach the $30 \%$ reduction in the total calorie, to meet for a declaration of "energy-reduced" according to the regulation of the European Union (Anon, 2006) and Turkish Food Additives Regulation (Anon, 2013).

\section{Acknowledgements}

The authors would like to thank to the Scientific Research Projects Units of University of Mersin, grant number BAP-MUH F GMB (SS) 2010-3A for the financial support of the present study.

\section{References}

Akoh, C. C. (1998). Fat replacers. Food Technology, 52, 47-52.

Alexander, R. J., \& Zobel, H. F. (1992). Developments in carbohydrate chemistry. St. Paul: AACC.

American Association of Cereal Chemists - AACC. (1995). Approved Method of American Association of Cereal Chemists. St. Paul: AACC.

American Association of Cereal Chemists - AACC. (2000). Approved Method of American Association of Cereal Chemists. St. Paul: AACC.

Anon. (2006). Regulation (EC) No 1924/2006 of The European Parliament and of The Council of 20 December 2006 on nutrition and health claims made on foods. Official Journal of the European Union, 404, 9-25.

Anon. (2013). Turkish Food Codex Regulation on Food Additives. Official Gazette, no. 28693.

Bath, D. E., Shelke, K., \& Hoseney, R. C. (1992). Fat replacers in highratio layer cakes. Cereal Foods World, 37, 495-500.

Bloksma, A. H., \& Bushuk, W.(1988). Rheology and chemistry of dough. In Y. Pomeranz (Ed.), Wheat chemistry and technology (Vol. 2, pp. 131-217). St. Paul: AACC.

Conforti, F. D., Charles, S. A., \& Duncan, S. E. (1997). Evaluation of a carbohydrate-based fat replacer in a fat-reduced baking powder biscuit. Journal of Food Quality, 20(3), 247-256. http://dx.doi. org/10.1111/j.1745-4557.1997.tb00468.x.

Dreese, P. C., Faubion, J. M., \& Hoseney, R. C. (1988). Dynamic rheological properties of flour, gluten, and gluten- starch doughs. 2. Effect of various processing and ingredient changes. Cereal Chemistry, 65, 354-359.

Feili, R., Abdullah, W. W., \& Yang, T. (2013). Physical and sensory analysis of high fiber bread incorporated with jackfruit rind flour. Food Science and Technology, 1(2), 30-36. http://dx.doi.org/10.13189/ fst.2013.010203.

Ghodke, S. K. (2009). Effect of guar gum on dough stickiness and staling in Chapatti: an Indian unleavened flat bread. International Journal of Food Engineering, 5(3), 1-19. http://dx.doi.org/10.2202/15563758.1317

Giese, J. (1996). Fats, oils and fat replacers. Food Technology, 50(4), 78-83.

Gómez, M., Ronda, F., Blanco, C. A., Caballero, P. A., \& Apesteguía, A. (2003). Effect of dietary fibre on dough rheology and bread quality. European Food Research and Technology, 216(1), 51-56. http://dx.doi. org/10.1007/s00217-002-0632-9.

Grigelmo-Miguel, N., Carreras-Boladeras, E., \& Martin-Belloso, O. (2001). Influence of the addition of peach dietary fiber in composition, physical properties and acceptability of reduced-fat muffins. Food
Science \& Technology International, 7(5), 425-431. http://dx.doi. org/10.1177/108201301772660484.

Güleç, M., Yabanci, N., Gocgeldi, E., \& Bakir, B. (2008). Ankara'da iki kiz ögrenci yurdunda kalan ögrencilerin beslenme aliskanliklari. Gülhane Tip Dergisi, 50, 102-109.

Hassel, C. A. (1993). Nutritional implications of fat substitutes. Cereal Foods World, 38(3), 142-144.

Hoseney, R. C., \& Smewing, J. O. (1999). Instrumental measurement of stickiness of doughs and other foods. Journal of Texture Studies, 30(2), 123-136. http://dx.doi.org/10.1111/j.1745-4603.1999.tb00206.x.

Khalil, A. H. (1998). The influence of carbohydrate-based fat replacers with and without emulsifiers on the quality characteristics of low fat cake. Plant Foods for Human Nutrition, 52(4), 299-313. http:// dx.doi.org/10.1023/A:1008096031498. PMid:10426117.

Khouryieh, H. A., Aramouni, F. M., \& Herald, T. J. (2005). Physical and

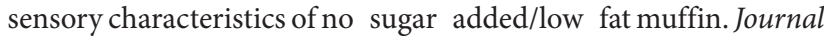
of Food Quality, 28(5区6), 439-451. http://dx.doi.org/10.1111/j.17454557.2005.00047.x.

Kieffer, R., Wieser, H., Henderson, M. H., \& Graveland, A. (1998). Correlations of the bread making performance of wheat flour with rheological measurements on a micro-scale. Journal of Cereal Science, 27(1), 53-60. http://dx.doi.org/10.1006/jcrs.1997.0136.

Kocer, D., Hicsasmaz, Z., Bayindirli, A., \& Katnas, S. (2007). Bubble and pore formation of the high-ratio cake formulation with polydextrose as a sugar-and fat-replacer. Journal of Food Engineering, 78(3), 953964. http://dx.doi.org/10.1016/j.jfoodeng.2005.11.034.

Ktenioudaki, A., \& Gallagher, E. (2012). Recent advances in the development of high-fibre baked products. Trends in Food Science \& Technology, 28(1), 4-14. http://dx.doi.org/10.1016/j.tifs.2012.06.004.

Lakshminarayan, S. M., Rathinam, V., \& Krishna Rau, L. (2006). Effect of maltodextrin and emulsifiers on the viscosity of cake batter and on the quality of cakes. Journal of the Science of Food and Agriculture, 86(5), 706-712. http://dx.doi.org/10.1002/jsfa.2400.

Lee, J. H., Akoh, C. C., \& Lee, K. T. (2008). Physical properties of trans-free bakery shortening produced by lipase-catalyzed interesterification. Journal of the American Oil Chemists' Society, 85(1), 1-11. http:// dx.doi.org/10.1007/s11746-007-1155-0.

Luzuriaga, D. A., Balaban, M. O., \& Yeralan, S. (1997). Analysis of visual quality attributes of white shrimp by machine vision. Journal of Food Science, 62(1), 113-118. http://dx.doi.org/10.1111/j.1365-2621.1997. tb04379.x.

Meilgaard, M. C., Civille, G. V., \& Carr, B. T. (2007). Sensory evaluation techniques (4th ed.). Boca Raton: CRC Press.

Mitchell, H. L. (1996). The role of the bulking agent polydextrose in fat replacement. In S. Roller \& S. A. Jone (Eds.), Handbook of fat replacers (pp. 235-249). Boca Raton: CRC Press.

Morris, C., \& Morris, G. A. (2012). The effect of inulin and fructooligosaccharide supplementation on the textural, rheological and sensory properties of bread and their role in weight management: a review. Food Chemistry, 133(2), 237-248. http://dx.doi.org/10.1016/j. foodchem.2012.01.027. PMid:25683391.

Nonaka, H. H. (1997). Plant carbohydrate-derived products as fat replacers and calorie reducers. Cereal Foods World, 42(5), 376-378.

O’Brien, C. M., Mueller, A., Scannell, A. G. M., \& Arendt, E. K. (2003). Evaluation of the effects of fat replacers on the quality of wheat bread. Journal of Food Engineering, 56(2), 265-267. http://dx.doi. org/10.1016/S0260-8774(02)00266-2.

Purlis, E. (2010). Browning development in bakery products: a review. Journal of Food Engineering, 99(3), 239-249. http://dx.doi.org/10.1016/j. jfoodeng.2010.03.008. 
Sanchez, C., Klopfenstein, C. F., \& Walker, C. E. (1995). Use of carbohydrate-based fat substitutes and emulsifying agents in reducedfat shortbread cookies. Cereal Chemistry, 72(1), 25-29.

Sevindi, T., Yilmaz, G., İbis, S., \& Yilmaz, B. (2007). Gazi Universitesi Beden Egitimi ve Spor Yuksek Okulu ogrencilerinin beslenme ve kahvalti aliskanliklarinin degerlendirilmesi. Turkish Journal of Social Research, 11(3), 79-90.

Shouk, A. A., \& El-Faham, S. Y. (2005). Effect of fat replacers and hullless barley flour on low-fat croissant quality. Polish Journal of Food and Nutrition Sciences, 14(3), 287.

Stauffer, C. E. (1998). Principles of dough formation. In S. P. Cauvan \& L. S. Young (Eds.), Technology of bread making (pp. 262-295). London: Blackie Academic and Professional.

Sudha, M. L., Srivastava, A. K., Vetrimani, R., \& Leelavathi, K. (2007). Fat replacement in soft dough biscuits: Its implications on dough rheology and biscuit quality. Journal of Food Engineering, 80(3), 922-930. http://dx.doi.org/10.1016/j.jfoodeng.2006.08.006.

Unsal, E. N. (2008). Diyet egitiminin hiperlipidemik hastalarin beslenme aliskanliklari, beslenme bilgi duzeyleri ve beslenme durumuna etkisinin degerlendirilmesi. Ankara: Gazi Universitesi, Egitim Bilimleri Enstitusu, Yuksek Lisans Tezi.

Yackel, W. C., \& Cox, C. (1992). Application of starch-based fat replacers. Food Technology, 46(6), 146-148.

Zahn, S., Pepke, F., \& Rohm, H. (2010). Effect of inulin as a fat replacer on texture and sensory properties of muffins. International Journal of Food Science \& Technology, 45(12), 2531-2537. http://dx.doi. org/10.1111/j.1365-2621.2010.02444.x.

Zoulias, E. I., Oreopoulou, V., \& Tzia, C. (2002). Textural properties of low-fat cookies containing carbohydrate-or protein-based fat replacers. Journal of Food Engineering, 55(4), 337-342. http://dx.doi. org/10.1016/S0260-8774(02)00111-5. 